\title{
GMR
}

\section{Chromosome variations and diversity of Epidendrum ibaguense Lindl. (Orchidaceae) on the Tepequém's Tepuy, Roraima, Brazil}

\author{
S.R. Nóbrega ${ }^{1}$, A.L.F. Coelho ${ }^{2}$, C.F. Verola ${ }^{3}$, I.R. Costa ${ }^{3}$, R. Vilaça ${ }^{4}$, \\ F.J.F. Luz ${ }^{4}$ and W.F. Araújo ${ }^{1}$ \\ ${ }^{1}$ Rede de Biodiversidade e Biotecnologia da Amazônia Legal, \\ Centro de Ciências Agrárias, Universidade Federal de Roraima, \\ Boa Vista, RR, Brasil \\ ${ }^{2}$ Programa de Pós-Graduação em Ensino de Ciência e Matemática, \\ Universidade Federal do Ceará, Fortaleza, CE, Brasil \\ ${ }^{3}$ Departamento de Biologia, Universidade Federal do Ceará, Fortaleza, CE, Brasil \\ ${ }^{4}$ Embrapa, Boa Vista, RR, Brasil \\ Corresponding author: S.R. Nóbrega \\ E-mail: sannarocha@gmail.com
}

Genet. Mol. Res. 16 (3): gmr16039754

Received June 20, 2017

Accepted August 14, 2017

Published September 21, 2017

DOI http://dx.doi.org/10.4238/gmr16039754

Copyright (C) 2017 The Authors. This is an open-access article distributed under the terms of the Creative Commons Attribution ShareAlike (CC BY-SA) 4.0 License.

\begin{abstract}
Studies addressing chromosome variations have elucidated many points regarding the taxonomy of the Orchidaceae. Epidendrum L. besides being one the largest orchid genera, present remarkable morphological, and inter- and intraspecific chromosome variations. Thus, based on a previous report on flower color variation in individuals of E. ibaguense (magenta, pink, white, and red), our aim was to determine its chromosome number and test whether this trait is associated with flower color variation in natural populations on the Tepequém's Tepuy, Roraima. Root apices were pre-treated with 8-hydroxyquinoline at $4^{\circ} \mathrm{C}$ for $24 \mathrm{~h}$ and subsequently submitted to conventional cytogenetic procedures. Slides with the best spreading and contraction of chromosomes were photographed under light
\end{abstract}

Genetics and Molecular Research 16 (3): gmr16039754 
microscopy. Chromosome number was determined by counting at least 10 mitotic metaphase cells per individual. The types of interphase nuclei were determined for 30 nuclei per individual. E. ibaguense presented intra- and interpopulation variation in chromosome number, with $2 \mathrm{n}=$ 58,72 , and 76 . The chromosome number $2 \mathrm{n}=58$ was most commonly found in individuals with magenta, pink, and white flowers, while the remaining two chromosome numbers occurred mostly in red-flowered individuals. The types of interphase nuclei were associated with the chromosome number. Individuals with $2 \mathrm{n}=58$ presented a predominance of semi-reticulated nuclei, while in those with $2 n=72$ and 76 the nuclei were predominantly non-reticulated. The dominance of disploidy in $E$. ibaguense suggests that this cytotype provides this species with a territorial advantage and a higher reproductive success, possibly contradicting the polyploid hypothesis. Our results suggest that chromosome number may not represent a reproductive barrier in genus Epidendrum.

Key words: Chromosomes; Hybridization; Cytogenetics; Amazon; Orchids

\section{INTRODUCTION}

Chromosome analyses provide strong support for plant biosystematics, especially when the variation is a key trait that helps to recognize the validity of a certain species (Stace, 1991). According to Guerra (1986) and Stace (1991), the divergence in chromosome number between morphologically close species can split distinct taxa, remarkably when the morphological variation is also present.

Thus, studies addressing chromosome variations have undoubtedly shed light into taxonomic statuses of the Orchidaceae, one of the largest Angiosperm families. Among the many genera composing this family, Epidendrum L. stands out with about 1500 described species (Chase et al., 2003). In Epidendrum, chromosome number can vary greatly, ranging from $2 \mathrm{n}=24$ in E. fulgens Brongn. to $2 \mathrm{n}=240$ in E. cinnabarinum Salzm. Despite such variation, chromosome number is currently known for only 3\% of the Epidendrum species. Apart from these interspecific differences, chromosome number varies within a given species, and even between neighboring populations (e.g., E. denticulatum Barb., 2n = 38, 40; E. radicans Pav. ex Lindl. Rodr., $2 \mathrm{n}=40,57,60,62,64,70$; and E. xanthinum Lindl., $2 \mathrm{n}=$ 28, 30, 40, 60, ca. 80) (Pinheiro et al., 2009; Felix and Guerra, 2010; Assis et al., 2013). The largest number of cytotypes is currently known for E. secundum Jacq., with $2 \mathrm{n}=28,40,48$, 52, 68, and 80 (Pinheiro et al., 2009) or $2 \mathrm{n}=30,42,50,54,56,58$, and 84 (Assis et al., 2013). Additionally, in E. secundum the chromosomes also vary in size, revealing a strong karyotypic asymmetry and bimodality (Assis et al., 2013).

When compared to dysploidy, polyploidy is considered a major adaptive mechanism in plants, expanding their ecological and geographic distribution (Briggs and Walters, 1997). Along with hybridization, polyploidy is recognized as a key process in plant speciation (Rieseberg, 1997; Grant, 1981). Studies suggest that polyploid organisms, which have more than two genomes in the same nucleus, have increased adaptability to harsh environmental conditions, as well as being good colonizers (Ramsey and Schemske, 1998; SchifinoWittmann, 2004; Fawcett and Van de Peer, 2010). Moreover, polyploidy is apparently related

Genetics and Molecular Research 16 (3): gmr16039754 
to subspecific morphological variation (Pinheiro and Cozzolino, 2013). In Epidendrum, besides chromosome number variations, morphological traits of the species also vary greatly (Dressler, 1993, 2005; Pinheiro and Barros, 2007; Pansarin and Amaral, 2008).

E. ibaguense Kunth. is distributed from Mexico to Bolivia, and is commonly found in rocky outcrops, at elevations ranging from $200-1000 \mathrm{~m}$, both in the savannas and Rain forests (Freitas, 2001; Luz and Franco, 2012; Flora do Brasil 2020 em construção, 2017). In Brazil, its distribution is limited to the North and Midwest regions, within the Amazon Domain (Tropicos. org domain, 2017; Flora do Brasil 2020 em construção, 2017). Individuals of E. ibaguense with different flower colors were reported on a "Tepuy" (Luz and Franco, 2012). This is a type of ancient, table-top Mountain with a particular flora (Alves et al., 2007). Based on this report, and given the great variation in chromosome number in genus Epidendrum, this study aimed 1) to determine the chromosome numbers, and 2) to test for an association between chromosome number and flower color variation in natural populations of E. ibaguense on the Tepequém's Tepuy, municipality of Amajari municipality, Roraima.

\section{MATERIAL AND METHODS}

\section{Study site}

We collected individuals of E. ibaguense from the Tepequém's Tepuy, in the municipality of Amajari/RR. The Tepequém's Tepuy is a remain of an eroded sandstone plateau, reaching up to $1100 \mathrm{~m}$. Its flora is composed mainly of grasses, shrubs, and subshrubs (Silva, 1997). The studied populations of E. ibaguense are located at the following coordinates: $3^{\circ} 45^{\prime} 56.96750^{\prime \prime} \mathrm{N}$ and $61^{\circ} 42^{\prime} 09.59398^{\prime \prime} \mathrm{W}$, at $831 \mathrm{~m}$ (population 1), and $3^{\circ} 45^{\prime} 55.34681 " \mathrm{~N}$ and $61^{\circ} 41^{\prime} 18.97437^{\prime \prime}$, at $1056 \mathrm{~m}$ (population 2).

\section{Sample selection and collection}

To determine the chromosome numbers of E. ibaguense, we selected individuals with different flower colors: magenta and pink (the most common individuals), and red and white (rare individuals) (Figure 1). The morphological characterization of vouchers used in the cytogenetic analysis is shown in Table 1.

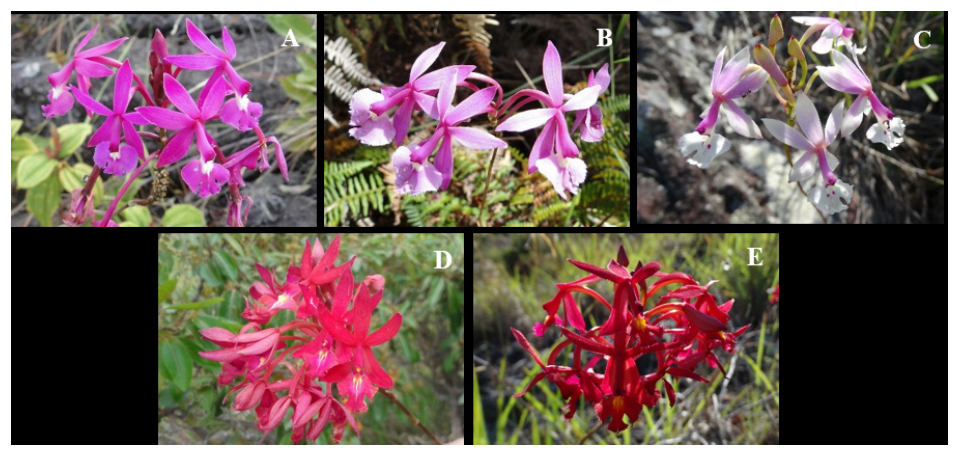

Figure 1. Flower color variation of Epidendrum ibaguense on the Tepequém's Tepuy/RR. A. magenta flowers; B. pink flowers; C. white flowers; D. terrestrial red flowers from population 1 (1); E. rupiculous red flowers from the population 2 (2).

Genetics and Molecular Research 16 (3): gmr16039754 


\section{Chromosome analysis}

We previously treated root apices of E. ibaguense with 8-hydroxyquinoline at $4^{\circ} \mathrm{C}$ for $24 \mathrm{~h}$, and postfixed the samples in Carnoy (ethanol:acetic acid, $3: 1$ ) at $4^{\circ} \mathrm{C}$. The root apices were hydrolyzed in $1 \mathrm{~N} \mathrm{HCl}$ for $10 \mathrm{~min}$ at $60^{\circ} \mathrm{C}$, smashed on glass slides, and stained with 2\% Giemsa for $20 \mathrm{~min}$ (adapted from Guerra, 1988). We photographed those slides with the best spreading and contraction of chromosomes under a light microscope. We determined the chromosome number for at least 10 mitotic metaphases per individual, and the type of interphasic nuclei in 30 samples per individual.

Table 1. Morphological traits of the vouchers used in the cytogenetic analysis.

\begin{tabular}{l|c|c|c|c|c|c}
\hline & \multicolumn{2}{|c|}{ Magenta } & Pink & White & \multicolumn{2}{c}{ Red (1) } \\
\hline Population & 1 & 2 & 2 & 2 & 1 & 2 \\
\hline Leaf length & 59.41 & 55.38 & 60.05 & 54.2 & 71.36 & 28.65 \\
\hline Leaf width & 2.63 & 2.4 & 1.87 & 1.81 & 2.77 & 3 \\
\hline Inflorescence length* & 65 & 113.75 & 78.5 & 36 & 137 & 25 \\
\hline Flower /Inflorescence & $5 \mathrm{~F} \mathrm{8B}$ & $5 \mathrm{~F} 8 \mathrm{~B}$ & $5 \mathrm{~F} \mathrm{9B}$ & $3 \mathrm{~F} 6 \mathrm{~B}$ & $8 \mathrm{~F} 18 \mathrm{~B}$ & $2 \mathrm{~F} 4 \mathrm{~B}$ \\
\hline Sepal length & 11.75 & 13.85 & 16.22 & 14.05 & 15.98 & 13.47 \\
\hline Petal length & 16.42 & 13.26 & 17.44 & 13.77 & 15.75 & 15.03 \\
\hline Labellum length & 19.7 & 18.99 & 18.13 & 19.27 & 19.54 & 19.37 \\
\hline Labellum diameter & 14.94 & 11.36 & 12.51 & 11.47 & 10.45 & 10.28 \\
\hline Column length & 9.49 & 8.69 & 11.95 & 9.07 & 10.05 & 9.98 \\
\hline Habit & Terrestrial & Rupicolous & Terrestrial & Terrestrial & Terrestrial & Rupicolous \\
\hline
\end{tabular}

Values are reported in millimeters, *except for inflorescence length, which is in centimeters. F- Flowers and B- Buds.

\section{RESULTS}

E. ibaguense presented intra- and interpopulation variation in chromosome number, with $2 \mathrm{n}=58,72$, and 76 (Figure 2), and $2 \mathrm{n}=58$ being most common in four individuals from both studied populations. This finding represents a valuable contribution to the cytogenetic status of $E$. ibaguense since $2 \mathrm{n}=70$ has been the only chromosome number report up to now (Pinheiro et al., 2009). At population 1, the terrestrial, magenta-flowered individual presented $2 n=58$, while the terrestrial, red-flowered individual sheltered in the shade presented $2 n=72$. At population 2, the rupiculous individuals with magenta, pink, and white flowers presented $2 n=58$, while rupiculous, red-flowered individuals exposed to the sunlight presented $2 n=76$. Moreover, in individuals with $2 \mathrm{n}=58$, interphasic nuclei were predominantly semi-reticulated, whereas in those with $2 \mathrm{n}=72$ and 76 nuclei were predominantly non-reticulated.

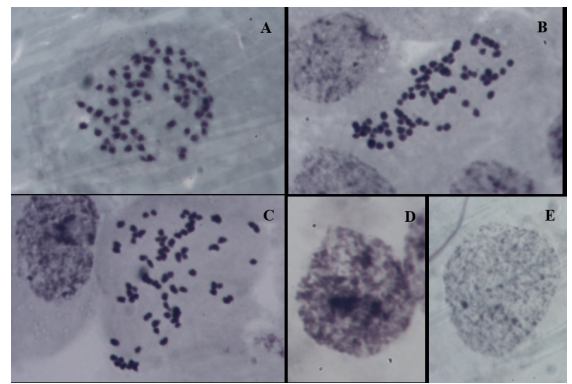

Figure 2. Metaphasic cells of Epidendrum ibaguense showing condensed chromosomes. A. $2 \mathrm{n}=58$, magentaflowered morphotype; B. $2 \mathrm{n}=72$, terrestrial, red-flowered morphotype (population 1 ); C. $2 \mathrm{n}=76$, rupiculous, red-flowered (population 2). Type of interphasic nuclei: D. semi-reticulated; E. non-reticulated.

Genetics and Molecular Research 16 (3): gmr16039754 


\section{DISCUSSION}

In E. ibaguense, the chromosome number was first reported by Pinheiro et al. (2009). These authors determined $2 \mathrm{n}=70$ for individuals from Serra de Pacaraima, located on the border between Venezuela and Roraima. In our study, in both studied populations, $2 \mathrm{n}=58$ was the most frequent chromosome number, while $2 n=72$ and $2 n=76$ were less frequent. Therefore, in both populations of the Tepequém's Tepuy, diploid individuals of $E$. ibaguense $(2 \mathrm{n}=58)$ may have greater reproductive and environmental success, as suggested by their higher local abundance. Our results suggest that in E. ibaguense, descendant and ascendant disployd events may have caused the chromosome variation in this species on the Tepequém's Tepuy.

According to Felix and Guerra (2010), in the subfamily Epidendroideae, only five of the 128 genera present a stable number of chromosomes. Epidendrum is one of the few genera that present variation in chromosome number, including at the intraspecific level [e.g., E. ciliare L., E. denticulatum, E. radicans, E. xanthinum, and in the complex E. secundum (Tanaka and Kamemoto, 1984; Pinheiro et al., 2009; Felix and Guerra, 2010; Assis et al., 2013) and E. ibaguense (this study)].

Such variation in chromosome number in Epidendrum suggests that determining a basic karyotype for this genus is uncertain, bringing about the difficulty in estimating the level of polyploidy and the karyotypic evolution in this taxon (Felix and Guerra, 2000). However, dysploidy (loss or gain of chromosomes) has been considered the most important evolutionary events in Orchidaceae (Felix and Guerra, 2010), while in plants as a whole, as well as in many orchid genera, polyploidy plays such a role (Felix and Guerra, 2000, 2005; Conceição et al., 2006).

It has been observed that highly polymorphic species are adapted to environmental conditions that impose strong selective pressures. Some groups within Orchidaceae that grow on inselbergs show levels of polyploidy higher than those related to epiphytic species (Felix and Guerra, 2010). In E. cinnabarinum, for instance, the intraspecific polyploidy seems to be related to the acquisition of the rupiculous habit (Felix and Guerra, 2010). Interestingly, this and other polyploid species are found in disturbed environments (Assis, 2009; Pinheiro et al., 2009; Felix and Guerra, 2010). Duplicated or repetitive gene sequence may provide a local advantage for polyploid organisms (Fawcett and Van der Peer, 2010). On the other hand, such a variation in chromosome number may not represent an effective reproductive barrier neither for Epidendrum nor the remaining groups of plants (Cozzolino et al., 2004; Marques et al., 2010).

E. ibaguense is phylogenetically close to the Andean clade, mainly distributed between the Andean Mountains and Guyana (Pinheiro et al., 2009; Pinheiro and Cozzolino, 2013). In Brazil, it is found exclusively in the Amazon, particularly on the studied Tepuy. Little is known about these types of mountains, and biological information concerning this orchid group is important to understand its evolution.

Flower color variation in E. ibaguense may be associated with the attraction of the different local groups of pollinators (Proctor and Yeo, 1973; Richards, 1996). In the Amazonian orchids, the most common flower colors are yellow, white, and lilac, which lie within the visible spectrum of bees (Ribeiro et al., 1999). Red flowers are invisible to bees and are uncommon in orchids (Faegri and Van Der Pijl, 1979). According to Weiss (1995), flower color change evolved in response to a pollinator-driven selection, which may represent a functional convergence in the angiosperms. Red-flowered individuals of E. ibaguense may be coevolving with a specific group of pollinators.

There are still knowledge gaps concerning Amazonian Orchidaceae, and, thus, much

Genetics and Molecular Research 16 (3): gmr16039754 
to be discovered about this family (Krahl et al., 2015). Moreover, studies addressing the origins of the tremendous diversity of Epidendrum are often constrained by the lack of model organisms capable of answering many fundamental questions about plant evolution (Pinheiro and Cozzolino, 2013). Therefore, punctual studies may fill such a gap about this orchid genus.

\section{Conflict of interest}

The authors declare no conflicts of interest.

\section{ACKNOWLEDGMENTS}

We thank to CAPES and FAPEAM for Doctorate scholarship for S.R. Nóbrega. This study is part of Doctorate's thesis of S.R. Nóbrega at Network Biodiversity and Biotechnology of the Legal Amazon, UFRR. FUNCAP - Fundação Cearense de Apoio ao Desenvolvimento Cientifico e Tecnológico (Grant \#10582430-5 - Programa Primeiros Projetos) and CNPq to Itayguara Ribeiro da Costa (\#479263/2011-6 - Edital Universal 2011). Authorization SISBIO \#40111-1.

\section{REFERENCES}

Alves RJV, Cardin L and Kropf MS (2007). Angiosperm disjunction "Campos rupestres - restingas": a re-evaluation. Acta Bot. Bras. 21: 675-685. https://doi.org/10.1590/S0102-33062007000300014

Assis FNM (2009). Variação numérica e evolução cariotípica em Epidendrum L. (Orchidaceae: Epidendroideae). Available at [http://www.cca.ufpb.br/ ppga/pdf/mestrado/Felipe\%20Nollet-ms09.pdf].

Assis FNM, Souza BCQ, Medeiros-Neto E, Pinheiro F, et al. (2013). Karyology of the genus Epidendrum (Orchidaceae: Laeliinae) with emphasis on subgenus Amphiglottium and chromosome number variability in Epidendrum secundum. Bot. J. Linn. Soc. 172: 329-344. https://doi.org/10.1111/boj.12045

Briggs D and Walters SM (1997). Plant variation and evolution. Cambridge University Press, Cambridge.

Chase MW, Cameron KM, Barrett RL and Freudenstein JV (2003). DNA data and Orchidaceae systematics: a new phylogenetic classification. In: Orchid conservation. Natural History Publications (Dixon KW, Kell SP, Barrett RL, Cribb PJ, eds.). Sabah, 69-89.

Conceição LP, Oliveira ALPC and Barbosa LV (2006). Characterization of the species Epidendrum cinnabarinum Salzm. (Epidendroideae: Orchidaceae) occurring in dunas do Abaeté-Salvador, BA-Brazil. Cytologia (Tokyo) 71: 125-129. https://doi.org/10.1508/cytologia.71.125

Cozzolino S, D'Emerico S and Widmer A (2004). Evidence for reproductive isolate selection in Mediterranean orchids: karyotype differences compensate for the lack of pollinator specificity. Proc. Biol. Sci. 271 (Suppl 5): S259-S262. https://doi.org/10.1098/rsbl.2004.0166

Dressler R (1993). Phylogeny and classification of the orchid family. Dioscorides Press, Portland.

Dressler R (2005). How many orchid species? Selbyana 26: 155-158.

Faegri K and Van Der Pijl L (1979). Principles of pollination ecology. 3rd edn. Pergamon Press, London.

Fawcett JA and Van der Peer Y (2010). Angiosperm polyploids and their road to evolutionary success. Trends Evol. Biol. 1: $17-21$.

Felix LP and Guerra M (2000). Cytogenetics and cytotaxonomy of some Brazilian species of Cymbidioid orchids. Genet. Mol. Biol. 23: 957-978. https://doi.org/10.1590/S1415-47572000000400041

Felix LP and Guerra M (2005). Basic chromosome numbers of terrestrial orchids. Plant Syst Evol. 254: 131-148.

Felix LP and Guerra M (2010). Variation in chromosome number and the basic number of subfamily Epidendroideae (Orchidaceae). Bot. J. Linn. Soc. 163: 234-278. https://doi.org/10.1111/j.1095-8339.2010.01059.x

Flora do Brasil 2020 em construção (2017). Epidendrum. Jardim Botânico do Rio de Janeiro. Available at [http:// floradobrasil.jbrj.gov.br/reflora/floradobrasil/FB37569]. Accessed April 18, 2017.

Freitas FL (2001). Orquídeas na Amazônia. Roraima: Boa Vista.

Grant V (1981). Plant speciation. Columbia University Press, New York.

Guerra M (1986). Reviewing the chromosome nomenclature of Levan et al. Rev. Bras. Genet. 9: 21-40.

Guerra MS (1988). Introdução à Citogenética Geral. Guanabara, Rio de janeiro.

Genetics and Molecular Research 16 (3): gmr16039754 
Krahl AH, Krahl DRP, Valsko JJ, Holanda ASS, et al. (2015). Biologia reprodutiva e polinização em orquídeas: com ênfase em espécies brasileiras e da região amazônica - uma revisão de literatura. Natureza on-line 13: 128-133.

Luz FJF and Franco J (2012). Orquídeas de Roraima. Embrapa, Brasília.

Marques I, Feliner GN, Draper Munt D, Martins-Loução MA, et al. (2010). Unraveling cryptic reticulate relationships and the origin of orphan hybrid disjunct populations in Narcissus. Evolution 64: 2353-2368.

Pansarin ER and Amaral MCE (2008). Reproductive biology and pollination mechanisms of Epidendrum secundum (Orchidaceae). Floral variation: a consequence of natural hybridization? Plant Biol (Stuttg) 10: 211-219. https://doi. org $/ 10.1111 / \mathrm{j} .1438-8677.2007 .00025 . \mathrm{x}$

Pinheiro F and Barros F (2007). Morphometric analysis of Epidendrum secundum (Orchidaceae) in southeastern Brazil. ए. Nord. J. Bot. 25: 129-136. https://doi.org/10.1111/j.0107-055X.2007.00010.x

Pinheiro F and Cozzolino S (2013). Epidendrum (Orchidaceae) as a model system for ecological and evolutionary studies in the Neotropics. Taxon 62: 77-88.

Pinheiro F, Koehler S, Corrêa AM, Salatino MLF, et al. (2009). Phylogenetic relationships and infrageneric classification of Epidendrum subgenus Amphiglottium (Laeliinae, Orchidaceae). Plant Syst. Evol. 283: 165-177. https://doi. org/10.1007/s00606-009-0224-2

Proctor M and Yeo P (1973). The pollination of flowers. In: Handbook of experimental pollination biology (Jones CE and Little RJ, eds.). Scientific and Academic Editions, New York.

Ramsey J and Schemske DW (1998). Pathways, mechanisms, and rates of polyploid formation in flowering plants. Annu. Rev. Ecol. Syst. 29: 467-501. https://doi.org/10.1146/annurev.ecolsys.29.1.467

Ribeiro JE, Hopkins MJG, Vincentini A, Sothers C, et al. (1999). Flora da Reserva Ducke: Guia de Identificação das Plantas Vasculares de uma Floresta de Terra-Firme na Amazônia Central. INPA, Manaus.

Richards PW (1996). Trees and shrubs: II. Reproductive biology. In: The tropical rain forest: an ecological study (Richards PW, ed.). Cambridge University Press, Cambridge, 101-120.

Rieseberg LH (1997). Hybrid origins of plant species. Annu. Rev. Ecol. Evol. Syst. 28: 359-389. https://doi.org/10.1146/ annurev.ecolsys.28.1.359

Schifino-Wittmann MT (2004). Poliploidia e seu impacto na origem e evolução das plantas silvestres e cultivadas. Rev. Bras. Agrociên. 10: 151-157.

Silva ELS (1997). A vegetação de Roraima. In: Homem, ambiente e ecologia no estado de Roraima (Barbosa RI, Ferreira EJG and Castellón EG, eds.). INPA, Manaus.

Stace CA (1991). Plant taxonomy and biosystematics. 2nd edn. Cambridge University Press, Cambridge.

Tanaka R and Kamemoto H (1984). Chromosomes in orchids: counting and numbers. In: Orchid biology: reviews and perspectives III (Arditti J, eds.). Cornell University Press, Ithaca.

Tropicos.org. (2017). Missouri Botanical Garden Available at: [http://www.tropicos.org/Name/23504348]. Accessed April18, 2017.

Weiss MR (1995). Floral color change: a widespread functional convergence. Am. J. Bot. 82: 167-185. https://doi. org/10.2307/2445525

Genetics and Molecular Research 16 (3): gmr16039754 